\title{
The Power of Vegetation as a Natural Resource: A Case of Kenya
}

\author{
George Ouma Ochola* \\ Rongo University, Department of Agronomy and Natural Resources, P.O. Box 103-40404, Rongo, Kenya
}

Submission: November 21, 2018; Published: December 03, 2018

*Corresponding author: George Ouma Ochola, Rongo University, Department of Agronomy and Natural Resources, P.O. Box 103-40404, Rongo, Kenya

Abstract

Environmental valuation has been critical in helping to accord the natural resources the right treatment and care so as to enable their sustainability. Natural resource utilization requires in depth understanding so as not to be focused only on their face value. We have been interacting and utilizing environmental resources like forest ecosystems but may be most of us have been looking at their instrumental value. There are many things that are hidden to use which can help us have a changed attitude on how we relate and utilize these resources. Previous scholars have noted that our development activities always turn to be the major threat to the environment. For instance, as a result of urbanization and industrialization, the environment together with its natural resources have been degraded. Various governments, Kenyan inclusive have tried to come up with policies and legislations to help protect these natural resources but at times their efforts have not been productive. Enactment of the Environmental Management and Coordination Act (EMCA) of 1999 was one of the milestones Kenya made to help protect the environment and its resources. EMCA together with the Physical Planning Act of 1996 provided for subjection of development activities to Environmental Impact Assessment (EIA) with the aim of protection of environment and its resources. Much has not been achieved with these. Various development activities still stand to degrade the environment and lead to depletion of natural resources like forest (vegetation). This sought to examine the importance of various environmental resources and hence prioritize them based on the researcher's understanding. This paper made a deduction that vegetation is the most important natural resource among other resources.

Keywords: Environment; Natural resources; Prioritization; Vegetation

\section{Introduction}

It has always come from the previous scholars that water is the second most important resource after oxygen. This implies that both oxygen and water normally precede other natural resources. The question that readers remain to ask themselves is the resource that occupies the third position. This question has triggered several others and there is need to analyze and seen whether or not these resources can be categorized or arranged in order of preference. As was mentioned earlier, we cannot understand the real value of these resources if we perceive them shallowly. For us to achieve this, we should embrace the life centered morality where man and other organisms are considered to have the same moral standing and possess intrinsic value. We should alienate ourselves from being anthropocentric and adopt a bio-centric individualism approach that takes away superiority from man and advocating for respect of other life-forms and minimizing impact on them. Similarly, we should also adopt the ecosystem centered morality where the non-individuals are also considered to have the moral standing and deserve respect.

\section{Discussion}

Considering the roles performed by various natural resources, it might be possible to prioritize them. This study relied on the already documented literature which were analyzed and the ones gathered online. As scholars, we are aware that oxygen is very important and water is also equally important. In order to get indepth of this, we should ask ourselves a few questions. But before this, let's briefly examine the roles performed by various natural resources.

\section{Oxygen as a resource}

As it is known to us, there can be no life without oxygen. It supports various life-forms on the earth's surface and even beneath water and soil. Various living organisms especially animals breathe in oxygen and release carbon dioxide. This carbon dioxide is also useful to plants especially green plants with chlorophyll. Oxygen can also be very useful in our laboratories and even in hospitals especially in the intensive care units where people are fighting for their lives and have developed a breathing problem. It worth noting that what has been given here as oxygen utilized by most life-forms is the one which is naturally made available. Writing these few advantages does not mean that the roles of oxygen are these few neither does it mean that oxygen is the most significant resource according to the previous scholars.

\section{Water}

If I am to go by what other scholars have adopted, I would consider this resource as the second most important. Some 
scholars have described water as 'life' and anything that disrupts its supply and distribution, disrupts the very survival of humanity [1]. This does not qualify that water is only useful to humanity alone. The challenge might have been mentioned above in the introduction. It is anthropocentrism that gives preference to humanity and fails to consider other living organisms to be having the same moral standing and deserve equal treatment. Water is a very significant resource to all life-forms on and underneath the earth's surface. Ever organismic needs water for its survival. Water supports the growth of plants and allows uptake of plant nutrients. It supports transport that takes place in both plants and animals.

Water has been used as a coolant in most of our industries. It has also supported generation of hydro-electric power. Water is a habitat for various aquatic organisms like fish among others. Water bodies contribute in cleaning our environments by acting as waste assimilators. Large water bodies have also served and offered a transport medium. We should also not forget that the presence of large water bodies also contribute in recharging atmospheric moisture thereby completing the hydrological cycle [2]. Similarly, cannot fail to mention the domestic use of water such as washing, bathing, drinking and even flashing toilets. Our agricultural activities are also supported by water. Just to uphold human character of prioritizing himself, water constitutes 70 $71 \%$ of the human body fluid. The other organisms, we might not be exact but what we know is that water is equally useful to them.

\section{Vegetation}

In most cases, forests and vegetation at large have not been categorized in terms of their value and how they contribute to the lives of other organism and even other resources. Man has always focused on the forests as source of bio-fuel, building materials and raw materials for the milling industries as was noted by [3]. The value that forests and vegetation add into the environment is mostly seen in flowers and the lawns [4]. This paper examined vegetation as one of the most important resources that has not received the attention they deserve. To start with, the role of forests and vegetation at large are unique and no other resources on earth can perform them. Vegetation, especially the ones that possess green colouring matter are able to synthesis oxygen through the process of photosynthesis [5]. As was stated earlier, oxygen has been considered the most important resource among other resources. Figure 1 shows the interaction between sunlight, carbon dioxide and a plant leaf that results in production of oxygen that is useful to human other organisms and sugar useful for both plants and animals. This process also leads to air purification.

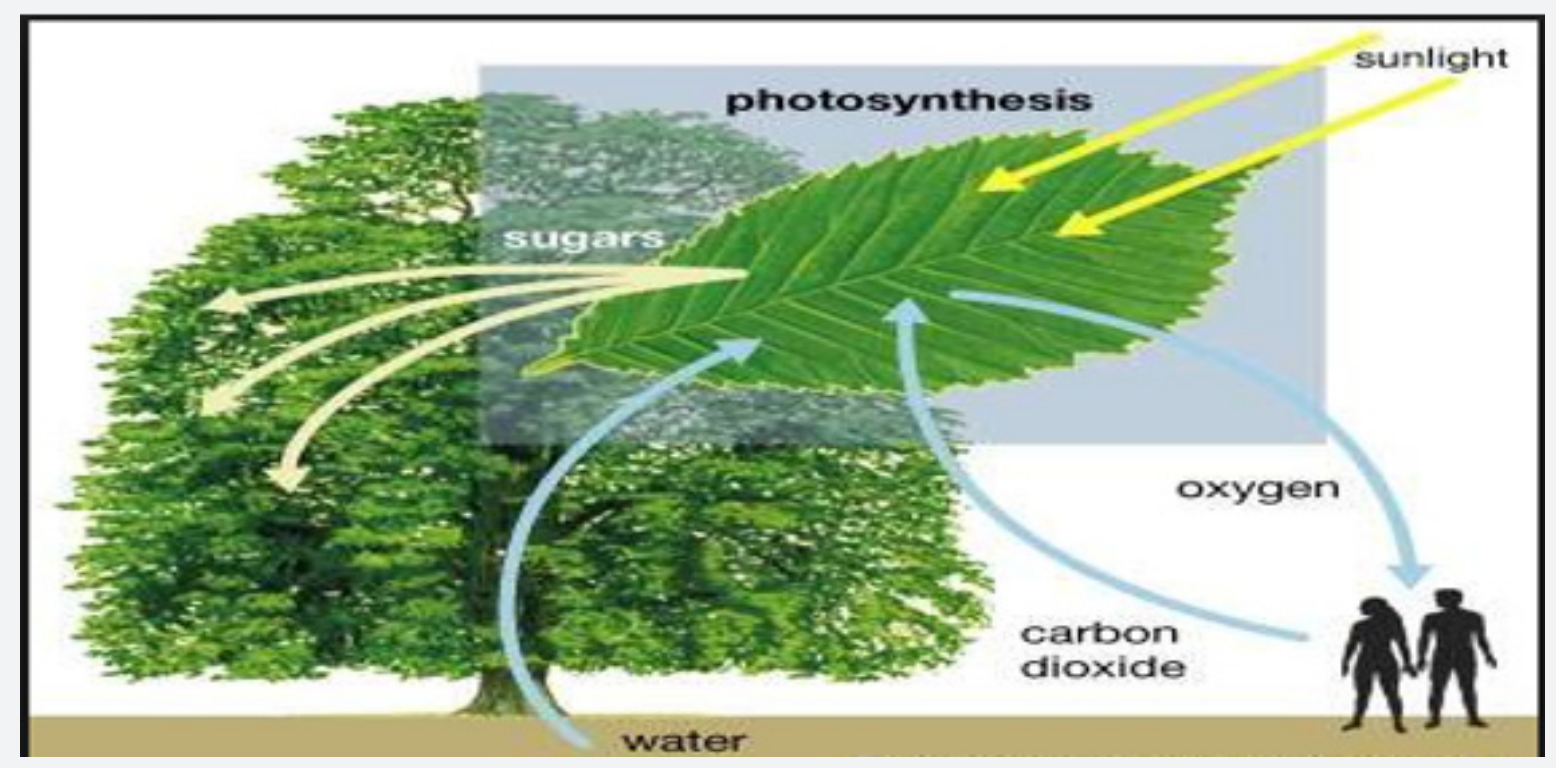

Figure 1: Power of a leaf in yielding oxygen through the process of photosynthesis. Source

Equally, vegetation act as carbon sinks [6]. They purify the air by taking in carbon dioxide. It is always known that carbon dioxide as one of the greenhouse gases contribute to global warming as it trap the emitted back infrared radiation into space by the earth. The consequences of global warming have been documented. Some of which include species extinction as a result of rapid climate change, rising sea level due to melting of glaciers and polar ice caps that may lead to flooding and its impacts, alteration of weather patterns that adversely impact on the lives of both plants and animals [7]. Anything that contributes in controlling and limiting the amount of carbon dioxide in the atmosphere positively contribute to the well-being of other organisms especially the animal species. There has been continuous release of carbon dioxide and other greenhouse gases into the atmosphere. Amazingly, vegetation was made to utilize this gas to generate its food as it releases oxygen.

Another significant role of vegetation when buffer zones are created to help protect water bodies [8]. Vegetation act as filters and trap the solid materials carried by the water run-off. This in most cases help to protect water bodies from siltation 
and leakage of nutrients that may cause eutrophication. This also help the water bodies to retain their depths. Similarly, the quality of water is also protected. Substances carried by runoffs that would otherwise harm the aquatic ecosystems are also trapped by vegetation. Additionally, vegetation controls the speed of water run-off [9]. When the speed is lowered as vegetation acts as obstacle, infiltration takes place thereby contributing in recharging ground water. This point shows how vegetation is important to both ground and surface waters. Figure 2 shows how vegetation can be used to protect the water resource when it acts as a buffer zone.

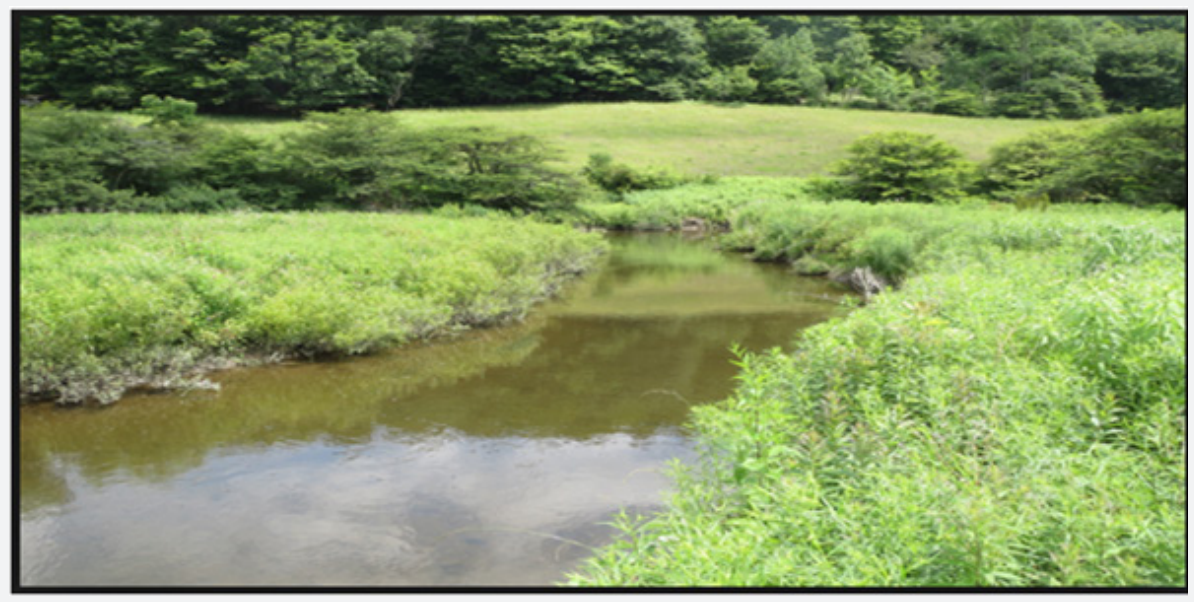

Figure 2: Buffer Zone for protection of river waters

The other role of vegetation is evident is the water cycle. For water cycle to be complete, there has to be evapotranspiration [10]. Plants and vegetation in general contribute to the recharge of atmospheric moisture. The previous point noted how vegetation contributes to protection of water quality and aquatic ecosystems. Under this point, we now note that for water to continue being there should be vegetation. In addition the presence of vegetation also controls evaporation rates as they act as wind breakers and may be used to protect surface water. What we call catmint areas are also made of vegetation. The moment these catmint areas are degraded and vegetation cleared, people start raising alarm on water shortage and other challenges associated with aridity and desertification .A good example of this is the degradation of Mau Forest Complex in Kenya which is considered a water tower and a catchment area supporting around twelve rivers. The consequences of depleting of this forest have been mentioned to include drying of rivers e.g. Mara River and loss of biodiversity. To some extent, it is becoming evident that without vegetation, there can be no water. Figure 3 is an indication of how vegetation contributes to completion of water cycle through evapotranspiration.

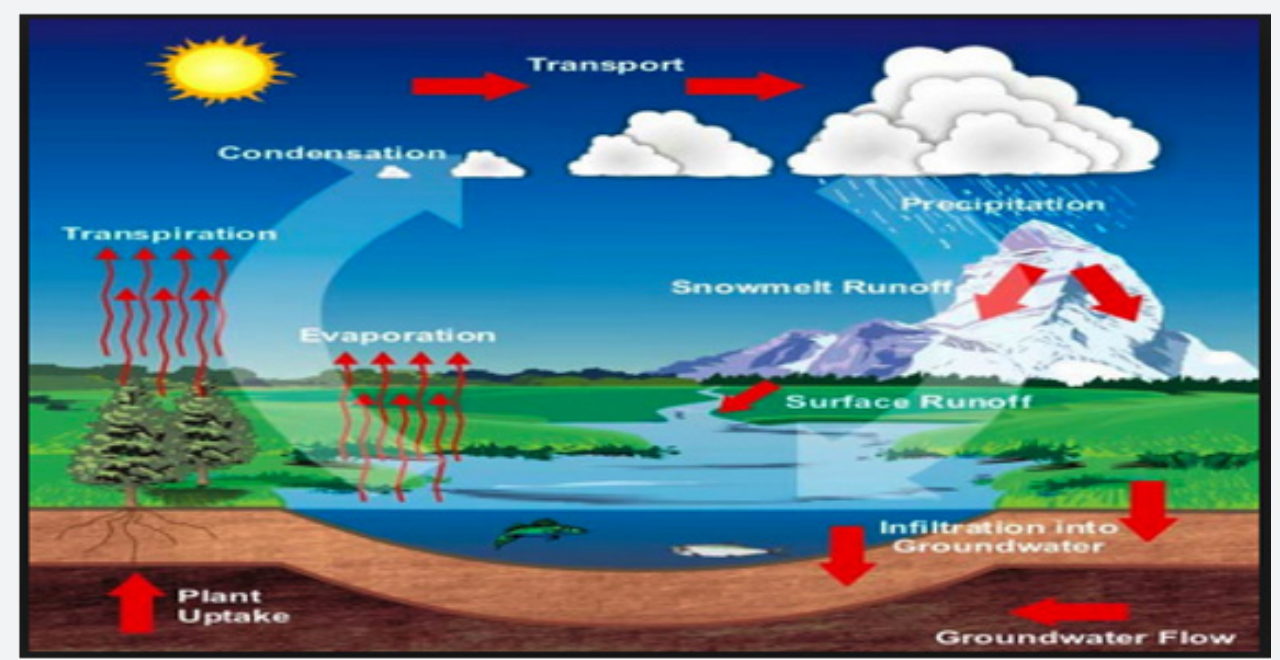

Figure 3: Vegetation as a contributor to water cycle.

Vegetation has played a significant role in soil protection. A part from humus that enriches the soil with nutrients, vegetation is important in controlling soil erosion. As was mentioned earlier, vegetation act as land cover and reduces the susceptibility of the soil to agent of soil erosion. They reduced the speed and force of various agents of erosion especially wing and water. It has also 
been noted that the roots of vegetation contribute to weathering of rocks and contribute to soil formation. Dead plants and are decomposed and enrich the soil with nutrient [11]. Vegetation may also reduce or lower the rate of weathering when they cover the rock surface and protect the rock from weathering agents. In an ecosystem, vegetation fall under the class of producers which are at the base. They act as the foundation and the basis upon which an ecosystem can be built. Without the producers, we can cannot attain the ecological balance neither can we maintain the food chains and food webs. This implies that we might not even talk about the trophic levels. Besides this, vegetation are habitats for various wild animals i.e. birds among other animals. Various animals find shelter and breeding places form vegetation. The role of vegetation as producers is almost the most significant as at brings a picture of vegetation especially the green plants to be the base of all other life-forms [10]. The primary, secondary, tertiary and the quaternary consumers are built on green plants (vegetation).

It sounds unfortunate that man as a consumer might have not realized that even himself is built on vegetation yet he considers himself as a moral agent with a moral standing and has always upheld anthropocentrism (human centered morality that does not consider the intrinsic value of other organisms). Vegetation has been perceived to regulate biogeochemical cycles like the one for carbon, water and nitrogen [7].

Not to forget, some vegetation and forest ecosystems act as tourists cites hence earning a country foreign exchange. Additionally, we have relied on vegetation as a source of food in form of fruits and many lives have also been saved by the herbs [3]. Vegetation and forest ecosystems have also been used as recreational areas and served various cultural functions where people can always go especially the elderly to pray to their gods when calamity befalls a particular community. They serve as the places of sacrifices. It is known that other resources like minerals also contribute to economic development of various countries. For the purpose of this paper, these other resources will be spared. I would only like to emphasize on these three resources whose roles are discussed above. That is oxygen, water and vegetation.

This paper was developed out of the concern for the vegetation which is a very important resource but has not received an appreciation that it deserves. Man has been undertaking his development activities with little or no concern at all on this resource. Agricultural activities has and still continue to contribute immensely to forests and other forms of vegetation. Land is being cleared almost on a daily basis to create room for agriculture and increased settlements as a result of rapid population increase. Industrial activities have also claimed large portions of land cover (vegetation). More land is being mechanized for more production to the industries, more buildings constructed, air polluted at a faster rate that makes vegetation to become overwhelmed of assimilation and eventually withers and dies.
Other human activities like mining have also led to loss of vegetation cover compromising the ecological roles performed by vegetation. The impacts of urbanization on vegetation can also not be over emphasized. Development and expansions on urban areas have led to clearance of vegetation. In most cases, it has been noted that in urban areas, vegetation cover is lost at a faster rate and this goes without compensation. The air is polluted with many vehicles emitting exhaust fumes together with emissions from industries located in the urban areas. These emissions overwhelm vegetation take-up. The only challenge that needs to be taken into consideration is that all these development activities together with rapid population increase.

Despite the various attempts to protect vegetation that have been noted from the various governments, little has been achieved. The Kenyan adoption or enactment of the Environmental Management and Co-ordination Act (EMCA, 1999) and the Forest Resources Act together with the Physical Planning Act of 1996 has not achieved much as was expected. The Acts provide for subjecting new development activities to Environmental Impact Assessment before the projects, programs or plans are initiated. This was to be monitored by the National Environment Management Authority (NEMA, Kenya). This has not been successful. Many development activities are still being undertaken without necessarily following these provisions. Other are done knowingly while other may come as a result of ignorance. Both of them have negatively affected vegetation cover.

Man has always prioritized what meets his immediate wants for example construction of residential structures and business premises to get monthly pays at the expense of vegetation that controls his present and future. The instrumental value assigned to this resource together with other resources has been the major cause of environmental degradation. We therefore need to understand the type of values we assign to these environmental resources. Vegetation is the primary source of oxygen that man relies on every second without pay. When this oxygen is not made available to man and any other organisms, there can be no life. Take for example a case where people and other living organisms have to rely on a laboratory oxygen. It becomes absolutely impossible to move on with life even for a minute. Vegetation makes it available to us free of charge but we have never appreciated. Our own negative attitudes on vegetation that makes us feel superior to other organisms will drive us to our graves. Most important resources are threatened and being depleted at faster rates by doing this we endanger our own lives on earth. Some scholars have always put it that we take care of the environment for the environment to take care of us.

This paper established that there is no other nature resource that can be compared to vegetation. This is comes true when we start analyzing the resources in terms of 'what makes the other available.' The simplest question we can ask ourselves is that "Can there be oxygen and water without vegetation?" The answer can be obvious yes somehow to some individuals. Someone will 
say that oxygen can be prepared in our laboratories and we can as well access ground water. I strongly disagree with such arguments. How many people and organisms can rely on oxygen generated from our laboratories for even a day? We noted earlier that vegetation contribute and controls infiltration into the soil hence contributing to underground water recharge. Similarly, we realized that vegetation, through evapotranspiration contribute to completing of hydrological cycle. Equally, we noted that the abundance and quality of water can be determined by the presence or absence of vegetation. It dawned on us that the water towers and catchment areas are made of vegetation and degradation and depletion of these catchment areas directly impact on abundance and quality of these water resources.

\section{Conclusion}

In my view, a product cannot be more important that what makes it available (source). The primary source of natural oxygen is vegetation (green plants) thus in categorizing these resources, vegetation becomes the mother and controller of these resources i.e. oxygen and water. Even though someone may argue that there can be no vegetation without water but the truth is, that is the interdependence within an ecosystem. Sincerely, vegetation makes oxygen available for use by man and other organisms. The quality of air in the atmosphere together with water resources is also determined by vegetation. As was noted earlier, vegetation play numerous roles that other resources do not. In that case, if I was privileged to categorize these three resources, vegetation would become first. This paper advocates for change of attitude by man in resource utilization. These natural resources own our future and we should accord the respect they deserve for us to prosper.

\section{References}

1. Schneider A, Arnold S, Doley D, Mulligan R, Baumgartl T (2012) The importance of plant water use on evapotranspiration covers in semi-arid Australia, Hydrol Earth Syst Sci Discuss 9: 11911-11940.

2. Madalinski KL, Gratton DN, Weisman RJ (2003) Evapotranspiration covers: An innovative. Approach to remediate and close contaminated sites, Remediation Journal 14: 55-67.

3. Wasonga O, Musembi J, Rotich K, Jarso I, King Okumu C (2016) Vegetation Resources and their Economic Importance in Isiolo County, Kenya. IIED, London.

4. Sabrina I, Suria S, Nur S (2014) Role of Ornamental Plants for Bird Community' Habitats in Urban Parks. Elsevier, Procedia Social and Behavioral Sciences 153: 666-677.

5. Jiake Z, Laura P, Ken D, Gary K, Knut K (2017) The Role of Vegetation Structure in Controlling Distributions of Vertebrate Herbivores in Arctic Alaska. Arctic, Antarctic, and Alpine Research 49(2): 291-304.

6. Sadroddin A, Martin W, Salman Q Qihao W, Thomas K (2015) The Role of Vegetation in Mitigating Urban Land Surface Temperatures: A Case Study of Munich, Germany during the Warm Season. Journal of Sustainability 7: 4689-4706.

7. Anders A (2015) Importance of vegetation dynamics for future terrestrial carbon cycling. Environ Res Lett 10: 054019.

8. Vickers H, Gillespie M, Gravina A (2012) Assessing the development of rehabilitated grasslands on post-mined landforms in northwest Queensland, Australia, Agriculture, Ecosystems, Environment 163: 7284.

9. Lynch KM (2007) Seasonal soil and plant water relations of rehabilitated sites in Gove, Northern Australia, PhD, Centre for Mined Land Rehabilitation, The University of Queensland, Brisbane, Australia.

10. Jingjie Y, Wang P (2012) Relationship between Water and Vegetation in the Ejina Delta. BCAS 1(26).

11. Robert G, Wagner M, Brian R, Ken McN (2006) The Role of Vegetation Management for Enhancing Productivity of the World's Forests. Advance Access publication 1(79): 55-67.

This work is licensed under Creativ Commons Attribution 4.0 License DOI: 10.19080/IJESNR.2018.15.555914

\section{Your next submission with Juniper Publishers} will reach you the below assets

- Quality Editorial service

- Swift Peer Review

- Reprints availability

- E-prints Service

- Manuscript Podcast for convenient understanding

- Global attainment for your research

- Manuscript accessibility in different formats ( Pdf, E-pub, Full Text, Audio)

- Unceasing customer service

Track the below URL for one-step submission https://juniperpublishers.com/online-submission.php 